\title{
WHAT IS SOCIAL RESILIENCE? LESSONS LEARNED AND WAYS FORWARD
}

\author{
Markus Keck and Patrick Sakdapolrak \\ With 1 table \\ Received 09. November 2012 · Accepted 20. March 2013
}

\begin{abstract}
Summary: Over the last decade, a growing body of literature has emerged which is concerned with the question of what form a promising concept of social resilience might take. In this article we argue that social resilience has the potential to be crafted into a coherent analytic framework that can build on scientific knowledge from the established concept of social vulnerability, and offer a fresh perspective on today's challenges of global change. Based on a critical review of recently published literature on the issue, we propose to define social resilience as being comprised of three dimensions: 1 . Coping capacities -the ability of social actors to cope with and overcome all kinds of adversities; 2. Adaptive capacities - their ability to learn from past experiences and adjust themselves to future challenges in their everyday lives; 3 . Transformative capacities - their ability to craft sets of institutions that foster individual welfare and sustainable societal robustness towards future crises. Viewed in this way, the search for ways to build social resilience - especially in the livelihoods of the poor and marginalized - is revealed to be not only a technical, but also a political issue.
\end{abstract}

Zusammenfassung: Innerhalb der vergangenen Dekade ist eine Vielzahl von Artikeln erschienen, die sich mit der Frage beschäftigen, wie ein der Forschung dienliches Konzept von sozialer Resilienz aussehen könnte. Wir argumentieren, dass ein in sich kohärentes Forschungsprogramm erstellt werden kann, welches nicht nur in der Lage ist, Ergebnisse aus der Verwundbarkeitsforschung aufzunehmen, sondern gleichsam neue Wege für die Erforschung aktueller Problemlagen aufzuzeigen vermag. Vor dem Hintergrund der gegenwärtigen Literaturlage schlagen wir eine Definition sozialer Resilienz vor, welche drei Dimensionen umfasst: 1. Die Fähigkeit sozialer Akteure zur Bewältigung von Krisen. 2. Das Vermögen, aus vergangenen Erfahrungen zu lernen und sich an zukünftige Entwicklungen anzupassen. 3. Die Befähigung zur sozialen und ökologischen Transformation, welche das individuelle Wohlergehen fördern und einer nachhaltigen gesellschaftlichen Stärkung im Umgang mit zukünftigen Krisen dienlich sind. In dieser Betrachtungsweise erscheint die Suche nach Resilienz - insbesondere für die Lebenshaltung der Armen und Ausgegrenzten - nicht als technische, sondern primär als politische Aufgabe.

Keywords: Social resilience, risk, vulnerability, adaptation, transformation, sustainable development

\section{Introduction}

The notion of resilience has become increasingly prominent in the last decade or so within several academic disciplines and research fields, from biology and engineering to sustainability studies and research into natural hazards and development issues. A controversial discussion has gained momentum regarding the question of whether or not resilience is a valid concept for the study of society. Today, a growing body of literature has emerged which is concerned with defining what form a promising conceptualization of social resilience might take. These developments have been subjected to deep criticism from both natural and social scientists. The ecologists BRAND and JAX (2007) have argued for constraining the application of the notion of resilience to ecosystems for reasons of conceptual clarity. As a "boundary object" (STAR and GriesEmer 1989; STAR 2010), resilience might facilitate the exchange of thoughts across disciplinary borders, which is necessary in order to develop a better understanding of coupled social-ecological systems. However, employing too broad a definition for the sake of a shared vocabulary might then make the term too vague and unmanageable, which in turn might even hinder scientific progress (BRAND and JAX 2007).

From a social science perspective, the geographers Cannon and Müller-Mahn (2010, 623) have argued that the concept of resilience is "inadequate and even false when it is being uncritically transferred to social phenomena". Due to its empirical heritage rooted in ecosystem sciences, the concept is feared to lead to the "re-naturalization of society" 
(Lidskog 2001) and to the re-emergence of a simplistic natural determinism (JudKINs et al. 2008). By advocating a positivistic, rationalistic and mechanistic way of thinking, it would disguise the essence of the issue: power relations (CANNON and MÜLLERMAHN 2010). As such, the concept bears the risk of "depoliticizing" social structures and unconsciously reinforcing the status-quo of society by overlooking those mechanisms that put people at risk in the first place (Pelling and Manuel-Navarrete 2011).

While acknowledging these critical voices, in our view the stated arguments are not sufficient to dismiss the concept as a whole. Instead we argue - and this is the central proposition of this paper - that social resilience retains the potential to be crafted into a coherent analytic framework that, on the one hand, is able to incorporate scientific knowledge from the tried and tested concept of vulnerability and, on the other hand, is forward-looking and opens up a fresh perspective on today's challenges of global change. Our proposition rests on a critical review of recently published literature on "social resilience"1) which was found by means of the two research engines, "Google Scholar" and "Web of Knowledge". All in all 68 relevant articles were identified that explicitly refer to the concept of "social resilience"; 13 were purely conceptual elaborations, while 55 presented empirical findings. These results were complemented with contributions that are, according to our knowledge and assessment, central to the discussion, even though the term "social resilience" was not explicitly mentioned. Giving the vast number of contributions on resilience, we cannot claim comprehensiveness regarding all conceptual refinements and empirical applications. Our aim is rather to provide a systematic overview of the main strands in the development of the concept of social resilience and to propose a framework which can guide future research in the field. In doing so, we want to provide a compass to help researchers to navigate through the increasingly complex body of literature, which will enable them to build on existing knowledge in order to make further progress in this research field. To this end, we investigate the roots of the concept of resilience and outline its genealogy, which leads to the iden-

1) This contribution explicitly focuses on literature referring to the concept of social resilience and is not intended to give an overview of the resilience literature in general. The literature on different types of resilience has grown rapidly (e.g. urban resilience, organizational resilience, community resilience, regional resilience) and cannot be adequately covered and discussed in a single review. tification of three fundamental principles (section 2). Subsequently, we discuss the varied definitions of social resilience and provide a short summary of empirical studies that have applied the concept so far (section 3). We then identify key mechanisms for building social resilience (section 4) and discuss possible ways to advance the study of social actors' navigating of contemporary spaces of risk and resilience (section 5). The article ends with concluding remarks on the development of the concept of social resilience.

\section{What is resilience?}

The concept of resilience has evolved stepwise from its initial emphasis on the general persistence of ecological system functions in a world that is subject to ongoing change, through an orientation towards coupled social-ecological systems and questions of the adaptation of humans in nature, to its most recent readjustment, in taking up the more critical question of social transformation in the face of global change. This particular genealogy - we suggest - is indicative of the underlying principles that constitute the resilience concept, i.e. persistability, adaptability, and transformability.

\section{Resilience as persistability}

Crawford Holling's (1973) article on "Resilience and Stability of Ecological Systems" is referred to as groundbreaking work in the study of resilience (e.g. WALKer and SALt 2006). By discussing examples such as spruce budworm outbreaks and their role for boreal forests in Canada (Holling 1973; Holling 1986; Holling 1996), Holling made the case that ecosystems would reveal nonlinear dynamics. With his paper, he radically called into question former static, equilibrium-based models of ecosystems. Instead he proposed to approach them as complex, adaptive systems that would retain cyclicity and exhibit a multitude of possible stable states, or "basins of attraction". With the notion of resilience, he addressed "the persistence of [ecological] systems and their ability to absorb change and disturbance and still maintain the same relationships between populations and state variables" (Holling 1973, 14). This (ecological) resilience was measured by the magnitude of disturbance that a system could tolerate and still persist (CARPENTER et al. 2001). Such an understanding was fundamentally different from 
the meaning implied by the more established term "stability", which described the ability of a system to return to an equilibrium state after a temporary disturbance (Holling 1996) and was also related to the time required for the system to return to this equilibrium (PIMM 1984). In shifting from the logic of stability to that of resilience, the emphasis was placed on those characteristics that enabled the system to live with disturbance and instability and which promoted its inherent flexibility and strengths that would increase its chances of persistence. Due to its clear-cut focus on ecosystems, at this stage, the concept of resilience remained widely unnoticed by social scientists.

\section{Resilience as adaptability}

In subsequent years, scholars of the Resilience Alliance, an international and interdisciplinary research network, further substantiated the idea of resilience by conducting empirical case studies on coupled social-ecological systems (WALKER et al. 1981; Walker 1993; Carpenter et al. 1999; Carpenter et al. 2001; WALKER et al. 2002). Empirical findings and conceptual considerations merged into the elaboration of the meta-theoretical model of the "adaptive cycle" (Holling 2001; Gunderson and Holling 2002; Berkes et al. 2003). The adaptive cycle is a heuristic model that portrays an endogenously driven four-phase cyclicity of complex systems. The general phases that these systems pass through are periods of 1) accumulation and growth, 2) stagnation, rigidity and lock-in, 3) sudden collapse, and 4) re-organization and renewal. With the notion of "panarchy", cross-scale dynamics and the interplay between nested adaptive cycles are addressed, in which the analyzed system is affected by both higher-ranked, slower cycles and subordinated, faster cycles.

In this second phase of the concept's lifespan, (social-ecological) resilience was defined as the "capacity of a [social-ecological] system to absorb disturbance and re-organize while undergoing change so as to still retain essentially the same function, structure, identity and feedbacks" (Folke 2006, 259). This definition served the aim of integrating the two ideas of ecological resilience and that of the adaptive cycle. As such, social-ecological resilience was defined as the magnitude of change the system could undergo and still remain within the same stable state (cf. ecological resilience), and the system's degree of self-organization (HoLLING 2001), understood as its capacity to re-organize after perturba- tions in an emergent and path-dependent manner (cf. adaptive cycle). In order to make the concept applicable for sustainability studies, the system's capacity for learning and adaptation was also included as third factor (BERKEs et al. 2003). With the notion of adaptation or adaptability, proponents of resilience thinking positioned themselves within the climate change discourse by raising the question of whether "humans in nature" might be able to combine their experience and knowledge to successfully adapt to global environmental change. Resilience emerged as a "boundary object" (STAR and GriesEMER 1989; STAR 2010) positioned between two communities of practice - i.e. natural and social sciences - and represented a means by which to allow for interdisciplinary collaboration and exchange.

\section{Resilience as transformability}

One of the fundamental ideas of resilience thinking was "that environmental problems cannot be addressed in isolation of the social context" (O'Brien et al. 2009, 5). As such, the concept of resilience could be seen as an invitation extended by natural scientists to social scientists to engage in integrative research under the banner and normative goal of sustainability. As a response to the critique of conservatism implicit in the reading of the concept of resilience as applied to social systems, which has been raised by critical social scientists (Pelling and Navarrete 2011), most recently, resilience proponents have updated their concept by adding the notion of transformation or transformability. As stated above, a system is seen to possess multiple potential stable states, or basins of attraction, which together constitute its "stability landscape" (GALLOPÍN 2006, 298). In being exposed to a specific shock or stress, or through changes in internal structures and feedback loops, the system might move from one basin into another, and thus exhibit changes in its functionality. The notion of transformability, then, addresses a system's capacity to transform the stability landscape and to create new system pathways when ecological, economic or social structures make the existing system untenable (WAlker et al. 2004; Folke et al. 2010). The word "untenable" (WALKER et al. 2004, 1) unmistakably addresses those issues that have so far been at the heart of the development discourse, i.e. equality, justice and human rights. This new focus on transformability can be said to have heralded the third phase of the concept's lifespan. 
Against this background, the genealogy of the concept of resilience can be summarized as having evolved stepwise from its initial focus on the persistability of ecological system functions, through an emphasis on the adaptability of coupled social-ecological systems, to its most recent reorientation towards addressing the transformability of society in the face of global change. By taking these three genealogical steps as highlighting the underlying principles that constitute the concept, resilience can be defined in its most general sense as a system's capacity to persist in its current state of functioning while facing disturbance and change, to adapt to future challenges, and to transform in ways that enhance its functioning. How can this concept be transferred to the social realm?

\section{What is social resilience?}

All definitions of social resilience concern social entities - be they individuals, organizations or communities - and their abilities or capacities to tolerate, absorb, cope with and adjust to environmental and social threats of various kinds. As OBRIST et al. (2010a, 289) pointed out, the entry point for empirical studies on social resilience is the question: "Resilience to what? What is the threat or risk we examine?" Threats are usually assumed to originate externally with regard to social units (e.g. impact of rising prices on household expenditure), but they might also stem from internal dynamics (e.g. impact of diseases on household income) or from interaction between the two (GALLOPíN 2006, 295). Turner et al. $(2003,8075)$ differentiate between stresses, which are characterized by continuous or slowly increasing threats (e.g. soil degradation) and perturbations, which refer to rapid-onset hazards (e.g. hurricane) to which social units are exposed. They emphasize that social as well as ecological events and dynamics can be considered as threats, and that social units are usually exposed to multiple stressors (see also LEICHENKO and O'BRIEN 2008).

The reviewed empirical case studies on social resilience address a wide range of threats. While some studies remain relatively broad and unspecific (CINNER et al. 2009), most other studies focus on specific stressors, which can be broadly grouped into three categories:

1. The first is centered on natural hazards and disasters and comprises studies on droughts (ROCKSTROM 2004; Pearce et al. 2010), floods (Braun and ABheuer 2011; Cashman 2011; Haase 2011; Lopez-Marrero and TsCHAKERT 2011), tropical storms (TompKins 2005; Frazier et al. 2010; Howe 2011; McSweeney and
Coomes 2011; Pelling and Manuel-Navarret, 2011), volcano eruptions (ToBIN and Whiteford 2002), tsunamis (AdGer et al. 2005; LARSEN et al. 2011; BigGs et al. 2012) and fires (Harte et al. 2009; McGee 2011).

2. A second group of papers addresses more long-term stress associated with natural resource management, resource scarcity and environmental variability. Case studies focus on issues such as mangrove forest conversion (ADGER 2000), maritime resource conservation (MARSHALL et al. 2009), desertification (BRADLEY and Grainger 2004), declining water quality (Gooch et al. 2012), water scarcity (LANGRIDGE et al. 2006) and climate variability and climate change (ENDField 2007; Hayward 2008; Rasmussen et al. 2009; Marshall 2010; Garschagen 2011; Marshall et al. 2011; DeshingKar 2012; SChefFran et al. 2012; Traerup 2012).

3. A third group of studies deals with various kinds of social change and development issues and examines policy and institutional change (THOMAs and TwYMAN 2005; Marshall 2007; Marshall and Marshall 2007; Marshall et al. 2007), migration (AdGer et al. 2002; Porter et al. 2008; Siegmann 2010), regional economic transformation (Evans 2008), tourism (ADAMS 2010), infrastructural development (PERZ et al. 2010), urban socio-spatial transformation (BouZAROVSKI et al. 2011), economic crisis and uncertainty (SCHWARZ et al. 2011; Zingel et al. 2011; KeCK et al. 2012), and health risks (LEIPERT and ReUtTer 2005; Hoy et al. 2008; Dongus et al. 2010; OBRist et al. 2010b).

All these studies have in common the fact that they use social resilience as their guiding concept. How do different authors define social resilience? The review shows that the emergence of the concept of social resilience shares certain similarities with the conceptual development of resilience, as described in section 2. It starts with a rather unspecific understanding of social resilience as the capacitity to respond, which then evolves as it incorporates notions of learning and adaptation to form a composite definition, and culminates in the acknowledgement of the importance of the roles played by power, politics and participation in the context of increasing uncertainty and surprise.

\section{Drawing on insights of vulnerability analysis}

A first definition of social resilience was provided by Adger $(2000,361)$ who considered it "as the ability of communities to withstand external shocks to their social infrastructure". Rather like the aforementioned understanding of resilience as the ability to persist, the focus of this definition was on the ca- 
pacities of social entities to protect themselves from all kinds of hazardous events. With a similar understanding in mind, Turner et al. (2003, 8075) incorporated the notion of resilience into their vulnerability concept and defined it as "system's capacities to [...] respond": These responses, they write, "whether autonomous action or planned, public or private, individual or institutional, tactical or strategic, shortor long-term, anticipatory or reactive in kind, and their outcomes collectively determine the resilience of the coupled system" (ibid. 8077).

Against this background one could argue that resilience is a combination of those elements that have been addressed in former concepts with the terms "coping strategies" and "adaptive capacity". However, the idea of resilience extends beyond these two elements. The concept of resilience is intrinsically dynamic and relies on the Heraclitean notion of "everything changes, nothing remains still". As such, it encompasses uncertainty, change and crisis as normal, rather than exceptional conditions. Therefore, the analysis of social resilience is geared toward understanding the mechanisms by which a system can adapt not only to the challenges that are directly at hand, but also to those that are unexpected and unknown (Kates and Clark 1996; Streets and Glantz 2000). Glavovic et al. (2003, 291) have made this explicit by defining social resilience as "the capacity to absorb [...] change - the ability to deal with surprises or cope with disturbances".

\section{Incorporating learning and adaptation into com- posite definitions}

In a second step the definition of social resilience was widened by including further skills and know-how that were deemed necessary for successfully dealing with uncertainty and change. Pelling $(2003,48)$, for instance, holds that social resilience is "a product of the degree of planned preparation undertaken in the light of a potential hazard, and of spontaneous or premeditated adjustments made in response to felt hazard, including relief and rescue". CUTTER et al. (2008) defines social resilience as "the ability of a social system to respond and recover from disasters" and states that it "includes those inherent conditions that allow the system to absorb impacts and cope with an event, as well as post-event, adaptive processes that facilitate the ability of the social system to re-organize, change, and learn in response to a threat." Both Pelling (2003) and CutTer et al. (2008) underline the anticipatory capacities and the pre-hazard preparedness of social actors and the capacity of a social system to learn from hazardous events how to better deal with it in future.

This positive feedback of learning from past crises to better deal with uncertainties in the future has given direction to new composite definitions. GLAVOvic et al. (2003, 290f.) have written that social resilience is basically "influenced by $[. .$.$] institu-$ tions $[. .$.$] and networks that enable people to access$ resources, learn from experiences and develop constructive ways of dealing with common problems". Based on these considerations, OBRIST et al. (2010a, 289) define social resilience "as the capacity of actors to access capitals in order to - not only cope with and adjust to adverse conditions (that is, reactive capacity) - but also search for and create options (that is, proactive capacity) and thus develop increased competence (that is, positive outcomes) in dealing with a threat". From this perspective, social resilience not only addresses social actors' or entities' capacities to protect themselves from all kinds of threats: in addition to absorptive capacities in the face of perturbations and stress, the idea of social resilience also implies that catastrophes may be perceived as opportunities for doing new things, for innovation and development (BoHLE et al. 2009). Being fully resilient, then, means coping with future crises by learning, through undergoing shocks and distress, about which actions are more or less appropriate in the context of uncertainties. Therefore the key question of social resilience is, as OBRIST et al. (2010a, 291) have pointed out, "what enhances capacities of individuals, groups and organizations to deal with threats more competently".

\section{Acknowledging power, politics and participation in transformation}

Even though this recent elaboration of the concept of social resilience may sound promising, many social researchers have deemed it too optimistic, since social actors' specific contexts are neglected. LORENZ (2010) has rightly pointed out that whether persons are able to cope with threats, learn from them, and adjust to future crises is not only decided by the persons themselves, or by their endowments and willingness to invest into mitigating and adaptive measures; most of all, it is a question involving all those societal factors that both facilitate and constrain people's abilities to access assets, to gain capabilities for learning, and to become part of the decision-making process. Therefore, at its heart, social resilience has to provide 
a suitable answer to the question of the interplay between social structures and the agency of social actors (Bohle et al. 2009).

Voss $(2008,45)$ has made clear that "the predominant opinion was that the pressure of an 'objective' problem was enough to initiate solution oriented processes. This was based on a fundamental trust that all problems today or in the future could be successfully dealt with through technology and science [...] in a cloud of apoliticalness". However, this opinion has turned out to be wrong; firstly, because the different perspectives and expectations of diverse stakeholders must be taken into account when coming to terms with today's challenges, and secondly, because there is no Habermasian ideal speech situation (LORENZ 2010). What types of threats are perceived, how they are dealt with, and whether the poor and marginalized are heard or not - all of these are questions related to actors' capacities to participate in governance processes (Voss 2008). If alternative or critical voices remain unheard for the sake of implementing standard solutions, the "participative capacity" of the system, and the unequal distribution of power and knowledge, become key issues of social resilience (e.g. Glavovic et al. 2003; Bohle et al. 2009; O'Brien et al. 2009; Davidson 2010; Lorenz 2010; ObrisT et al. 2010a). In reality, there are situations that make shifts in dealing with risks necessary which exceed established methods of coping and adapting. These shifts might include technological innovations and policy reforms, like Germany's nuclear power phase-out and related policies to foster renewable energies. Such shifts are, however, strongly influenced by social factors (ethics, knowledge, attitudes to risk and culture) and social thresholds and start with people's questioning of their everyday lives and routines, their norms, values and taken-for-granted assumptions about reality (Adger et al. 2009; O’Brien 2011; Christensen and Krogman 2012). Hence, BÉNÉ et al. (2012) have rightly underscored that there are considerable barriers to societal transformations that are rooted in sys- tems of power and knowledge, which are often deeply entrenched in the social structures and protected by powerful interests.

\section{Three capacities of social resilience}

The state of the current debate over how to define social resilience has reached a point where several authors such as Voss (2008), LORENZ (2010), OBRIST et al. (2010a), BÉNÉ et al. (2012) and KECK (2012) have suggested that three different types of capacities are necessary for understanding the notion of social resilience in its full meaning. These are labelled coping capacities, adaptive capacities and transformative capacities. In the rows in table 1 we list four criteria in order to make the distinct meanings of these three terms explicit. The first criterion refers to people's response to risks, and distinguishes between ex-ante and ex-post activities. The second criterion, the temporal scope, refers to the time horizon that is addressed. A continuum is spanned between agency based on immediacy and short-term thinking, and project-related, calculative agency based on a more long-term rationale. The third criterion refers to the degree of change undergone by social structures, and the fourth to the outcomes that are associated with the three capacities.

By means of these four criteria, we can place each of the above mentioned capacities in a matrix of social resilience:

1) Coping capacities address "re-active" (ex-post) (OBRIST 2010a, 289) and "absorptive" (BÉNÉ et al. 2012, 21) measures of how people cope with and overcome immediate threats by the means of those resources that are directly available. The rationale behind coping is the restoration of the present level of well-being directly after a critical event.

2) Adaptive capacities refer to the "pro-active" (exante) (OBRIST 2010a, 289) or "preventive" measures (BÉNÉ et al. 2012, 31) that people employ to learn from past experiences, anticipate future risks and ad-

Tab. 1: Three capacities of social resilience

\begin{tabular}{llll}
\hline & Coping capacities & Adaptive capacities & Transformative capacities \\
\hline Response to risk & ex-post & ex-ante & ex-ante \\
Temporal scope & short-term & long-term & long-term \\
Degree of change & low, status quo & $\begin{array}{l}\text { medium, incremental } \\
\text { change }\end{array}$ & high, radical change \\
Outcome & restoration of present level & $\begin{array}{l}\text { security of future well- } \\
\text { of well-being }\end{array}$ & $\begin{array}{l}\text { enhancement of present and } \\
\text { future well-being }\end{array}$ \\
\hline Source: Own draft based on Voss (2008), Lorenz (2010), OBRist et al. (2010a), BénÉ et al. (2012), KECK (2012)
\end{tabular}


just their livelihoods accordingly. Adaptation is geared toward incremental change, and serves to secure the present status of people's well-being in the face of future risks. The major difference between coping and adaptation is grounded in the temporal scope of the activities involved. While coping addresses tactical agency and short-term rationale, adaptation involves strategic agency and more long-term planning.

3) Finally, transformative capacities, or "participative capacities" in the words of Voss (2008) and LoRENZ (2010), encompass people's ability to access assets and assistance from the wider socio-political arena (i.e. from governmental organizations and so-called civil society), to participate in decision-making processes, and to craft institutions that both improve their individual welfare and foster societal robustness toward future crises. The main difference between transformation and adaptation refers to the degree of change and the outcome it implies. Transformation is geared towards a radical shift in which the objective is not to secure, but to enhance people's well-being in the face of present and/or future risks. As such it explicitly incorporates topics of progressive change and development.

So far, there is no systematic assessment of the relation between the three dimensions of social resilience, which are often considered as a linear sequence that is traversed according to the degree of stress social actors are exposed to or the degree of agency involved (BÉNÉ et al 2012). However, while positionality within social systems might influence the endowment of social actors with different capacities, it would be misleading to understand these three terms as static power markers of different societal sections. Empirical case studies suggest rather that all three dimensions of agency can be found in principle among all actors at all scales, albeit to very different extents depending on the context (KECK and ETZOLD in this volume). In accordance with ADGER et al. (2011) we thus consider the following questions to be most pressing from the perspective of development studies: under what conditions might the three dimensions of social resilience mutually enforce each other? And in what cases might one capacity undermine another?

\section{Social resilience by what means?}

In contrast to the general notion of resilience, the understanding of social resilience is deeply influenced by insights from the social sciences, and addresses questions of human agency, social practices, power relations, institutions, and discourses - facets that have been widely ignored in studies of ecological resilience. After having presented the key capacities in the section above, in the next step, we will address the question of key determinants of social resilience, i.e. social relations and network structures; institutions and power relations; and knowledge and discourses.

\section{Social relations and network structures}

As social resilience is closely related to the idea of capacity (CANNON 2008), authors such as MAYunga (2007) and OBRist et al. (2010a) draw on insights from the social vulnerability and livelihoods approach and point to the importance of endowment with different kinds of assets as a crucial determinant of social resilience (see also CinNer et al. 2009). These studies refer to a broad variety of assets, e.g. economic capital, physical capital, natural capital, human capital, etc. However, against the background in which assets are widely acknowledged to be products of social relations (SAKDAPOLRAK 2010, 57-60), social capital is recognized as playing a key role in building and maintaining social resilience (see e.g. Adger 2000; Adger et al. 2002; Pelling and High, 2005; Wolf et al. 2010; SChefFran et al. 2012).

Studies that deal with this issue can be subdivided into those that predominantly analyze the structure of social networks and those that focus on the meaning and content of social relations (KECK et al. 2012). Studies by ERnSTSON and colleagues (ERNSTSON 2008; ERNSTSON et al. 2010a and 2010b) are examples of the first group of studies. Authors like Bodin et al. (2006) have tried to assess the optimal case-specific ratio of strong and weak ties necessary in order to build social resilience. And Moore and Westley (2011) have argued that network theory helps to explain the types of networks needed for social resilience. However, they have admitted that the mere presence of network structures does not guarantee that innovation will take place. What is crucially needed are "institutional entrepreneurs" that make innovative processes happen.

Pelling and High (2005), Traerup (2012) and KECK et al. (2012) represent the second group of studies, which place emphasis on the content of social relations and on the critical roles of trust, reciprocity and mutual support. Pelling and High (2005) have suggested that informal social interactions are communities' best resources for maintaining their capacities to build social resilience and to change collective direction. KECK et al. (2012) have made clear that informal networks play a decisive role in urban food supply in cities of developing 
countries. While most authors consider social capital an enabling resource for resilience-building, BOHLE (2006) has given attention to the dual nature of social networks; sometimes enabling, but sometimes constraining and exclusionary.

\section{Institutions and power relations}

As with assets, questions of access have also come into the focus of social resilience research. In attempting to understand people's access to resources, several authors have stressed the importance of institutions, understood as those rules and norms that both structure and are structured by social practices (ETzold et al. 2012). Adger (2000, 354), for instance, states that "social resilience is institutionally determined, in the sense that institutions permeate all social systems and institutions fundamentally determine the economic system in terms of its structure and distribution of assets". In this regard, HutTer (2011), GARSCHAGEN (2011) and KeCK (2012) have proved the usefulness of studying social resilience through the lenses of neo-institutional organization theory. From an empirical point of view, VARGHESE et al. (2006) have pointed out the importance of a differentiated view of the role that access to land plays in community resilience. LANGRIDGE et al. $(2006,12)$ have illustrated in their case study how the capacities of Northern Californian communities to deal with water scarcity are not directly influenced by the availability of water, but by the "historically contingent mechanism to gain, control and maintain access to water". In consequence, the authors rightly plead for an analysis of the full array of structural and relational access mechanisms.

The issue of access has brought questions on equity, justice and power into the agenda. In this regard, OBRist et al. (2010b) have made clear the importance of people's cultural capital - in the form of gender, kinship or ethnic role models - in determining their access to malaria health care. GLAVOviC et al. (2003) have argued in their account that resilience at one level of a community does not necessarily improve resilience at another level, and CANNON $(2008,12 \mathrm{f}$.) has argued that "[c]ommunities are places where normal everyday inequality, exploitation, oppression and maliciousness are woven into the fabric of relationships." Accordingly, he argues that communities must be understood as places of unequally distributed vulnerabilities and unequally distributed potentials for dealing with them. From this perspective, the process of building, conserv- ing and reproducing social resilience appears as a highly contradictory and even conflictive process. Additionally, it is important to note that "(o)ptimizing for one form of resilience can reduce other forms of resilience" (WALKER and SALT 2006, 121). In other words, resilience is costly, and it is important that it is achieved under conditions of finite resources and limited, though available, options for action. Hence, studies of social resilience must always address the question of who are the winners and losers of ongoing processes of building social resilience.

\section{Knowledge and discourses}

Recent studies of social resilience emphasize the roles of knowledge and culture. Marshall and Marshall $(2007,10)$ have suggested "that perception of risk should be included in future conceptual models of resilience". Their study shows how ranchers in Australia and the USA overestimate their capacity to cope and adapt to climate variability, and how this misperception makes them vulnerable to more extreme climate events (see also Marshall 2010). Likewise, Furedi $(2007,485)$ has argued that the ways in which people "cope in an emergency or a disaster are shaped by [...] a cultural narrative that creates a set of expectations and sensitises people to some problems more than others". As such, "perceptions of risk, preference, belief, knowledge, and experience are key factors that determine, at the individual and societal level, whether and how adaptation takes place" (SCHWARz et al. 2011, 1138).

Voss (2008) has convincingly shown that social resilience is a matter of people's power to define what is perceived as a threat or disaster and what is not, whereas hegemonic discourses are always dominating while the subaltern are seldom heard. LORENZ (2010) argues for understanding the resilience of social entities from the point of view of their symbolic order of meaning. Kunlicke (2010) speaks of the "myth of resilience", in order to highlight its social construction and related underlying mechanisms. In his study on flood management in a German municipality, he has shown that resilience, as a discursive formation, can become a powerful vehicle for establishing and consolidating new power relations within the municipality. In her study in Northern Ghana, Olwig (2012) has pointed to the multi-sited construction of local resilience as a result of the interaction of powerful global organizations with local populations. As such, resilience is a product of both local and global imaginaries and 
discourses. All these studies emphasize the importance of questioning by whom, for what purpose, and with what consequences various worldviews are transported through the notion of resilience. In this regard, "resilience theory [...] needs to acknowledge and incorporate much more explicitly [the] role of stakeholder agency and the process through which legitimate visions of resilience are generated" (LARSEN et al. 2011, 491). As ERNSTSON $(2008,174)$ has argued, what is required is a clear-cut focus on the longer-term formation and reproduction of (hegemonic) discourses - a focus that urges social scientists to think of knowledge and power as dynamic and interrelated components of the fabric of our social world.

\section{Ways forward in social resilience research}

We draw two major findings from our literature review as presented above: first, social resilience is best understood as a concept in the making. In fact, the questions of how social resilience can be properly defined, how it can be operationalized, measured and analyzed, and how it might be fostered (or hindered) are far from being settled yet. As such, at present, it is too early to make any final decision about the validity and usefulness of the concept for social science-oriented research agendas. At the same time - this is our second finding - three fundamental principles of social resilience can be identified that make it a concept in the making. The concept of resilience in general terms was shown to have evolved stepwise from its initial focus on the persistence of system functions, through an emphasis on adaptation, to its most recent reorientation towards addressing the transformation of society in the face of global change. In loose correspondence with these genealogical steps, the idea of social resilience was developed from its initial meaning, referring simply to actors' capacity to respond, and enlarged to encompass actors' capacity to learn and adapt; now the concept also includes their capacity to participate in governance processes and to transform societal structures themselves. From our point of view, the concept of social resilience in its current state removes much of the concerns raised by BRAND and JAX (2007) with regard to conceptual clarity.

Despite their loosely coupled genealogies, the actor-oriented concept of social resilience elaborated by social scientists departs significantly from the concept's original meaning. Social scientists place the spotlight on social actors, rather than on systems, and focus on capacities and practices instead of functionalities. This shift has been necessary, as it has brought important issues such as power, politics and participation back onto the agenda of the resilience debate. In our view, this mitigates much of the concern expressed by CANNON and MÜLLERMAHN (2010) with regard to the potentially depoliticizing effect of applying of the concept of resilience to social contexts, and its tendency to reinforce the status quo. At the same time, we are aware that the current path of development of the concept of social resilience bears the risk of losing sight of the importance of context, feedbacks and connectedness that the resilience concept put on the agenda of risk studies in the first place (Nelson et al. 2007). We therefore consider the current challenge to be that of finding ways to balance and reconcile insights from both perspectives. We argue that this balance can be achieved by systematically integrating three aspects into social resilience analysis.

First, a resilience perspective, as NELSON et al. (2007, 399) highlight, implies the relatedness and coupling of social and ecological spheres, which cannot be understood in isolation from one another. As the review has revealed, the interlinked character of these two spheres has been deemphasized in studies on social resilience, in favor of an emphasis on the social sphere alone. Ecological systems are addressed mainly in the form of stress factors impinging on social units. In our view, the concept of "hazardscapes" developed by Mustafa (2005) and the related concept of "riskscapes" suggested by Müller-Mahn and EverTs (2013) are able to address the issue of social-ecological coupling, and minimize the risk that ,hazards' will be treated simply as ,natural events' originating outside the social sphere altogether. Having been inspired by the idea of landscape in Geography, Mustafa (2005) points out that the concept of "hazardscapes" acknowledges both the "constructedness of nature in human contexts" and "nature in the realist sense" (Escobar 1999, 2). Landscape is understood as "the materialised result of complex human-environment relations" (FOR 1501 2010, 7). The concept, thus emphasizes the hybrid character of human-environmental relations and admits that the experience of hazards "is not just a function of the material geographies of vulnerability but also of how those hazardous geographies are viewed, constructed, and reproduced" (MUSTAFA 2005, 566). In addition it also draws attention to the pluralistic character of hazards, in temporal, spatial and social terms. 
Secondly, we argue that a social resilience analysis that acknowledges "context, feedback and connectedness" (NELSON et al. 2007) can be crafted on the basis of a relational understanding of society as proposed by Pierre Bourdieu. Authors such as OBRist et al. (2010a) have already drawn on Bourdieus notions of "field", "habitus" and "capital" and argue that actors' risk exposure and social resilience differ depending on their positions in the field (which are determined by their capital) and their practices (which are determined by their habitus). Siegmann (2010) and Cannon (2008) have highlighted that there might be "winners" and "losers" in resilience-building processes - even within the same community or household. With Bourdieu's notions it becomes possible to analyze fields of social resilience, to identify the probable winners and losers in these fields and - most importantly - to relate them to each other. Such a view enables us to raise another question of future interest; that is: resilience in whose interest?

Thirdly, many studies on social resilience have emphasized the local level, which is deemed to be the crucial level of analysis. However, as Olwig (2012) has made clear, social resilience must be understood as a product of the interaction between global and local forces. Apart from rare exceptions (e.g. LYON 2011), at present a systematic discussion of the relation between social resilience, scale and place is still lacking. We consider the concept of "translocality", as outlined by Greiner and SAKDAPOLRAK (2012; see also Greiner and Sakdapolrak 2013), to be suitable for the analysis of social resilience in the context of cross-scale dynamics. The authors distinguish between "places", referring to locations in the physical environment where face-to-face communication takes shape, and "locales", referring to settings for social interaction that stretch beyond places, and which become "translocales" by means of remote interactions (GREINER and SAKDAPOLRAK 2012). With the concept of "translocality", social resilience can be conceived of as the outcome of pluri-local embeddedness of social actors, which are increasingly gaining importance under the present condition of ongoing globalization.

\section{Conclusion}

This paper has focused on the concept of social resilience. This notion shares the key principles of the general resilience concept, which is rooted in and dominated by ecological systems thinking, specifically in its focus on systems' persistability, adaptability, and transformability. However, it departs from the general resilience discourse by adopting an actor-oriented perspective. Through the establishment of this approach to social resilience, the threat of a re-emergence of the social application of oversimplistic concepts of natural determinism has been counterbalanced, and politics has been brought back into the discussion.

Based on our review of the literature, we have identified three important dimensions of social resilience, which together take into account social actors' capacities to cope with and to overcome all kinds of immediate adversities (coping capacities), their capacities to learn from past experiences and adjust themselves to pressing new challenges in the future (adaptive capacities), and their capacities to craft institutions that foster individual welfare and sustainable societal robustness in the event of present and future crises (transformative capacities).

As this review illustrates, the concept of social resilience shares several commonalities with the social vulnerability and livelihoods approach (for an overview see Manyena (2006) and Miller et al. (2010). However, there are also important differences. We argue that the concept of social resilience contributes new perspectives to the understanding of vulnerable groups under stress. Firstly, the concept recognizes uncertainty, change and crisis as normal, rather than exceptional. The world is conceived of as being in permanent flux. In consequence, social resilience is perceived as a dynamic process, rather than as a certain state or characteristic of a social entity. Secondly, the study of social resilience emphasizes the embeddedness of social actors in their particular time- and placespecific ecological, social and institutional environments. As such, it is a relational rather than an essentialist concept. Thirdly, social learning, participative decision-making, and processes of collective transformation are recognized as central aspects of social resilience. Social transformations are never deterministic, but are open to debate, despite the fact that hegemonic discourses and technical innovation may play important roles in defining potential directions for development. To sum up, then, social resilience is not only a dynamic and relational concept, but also a deeply political one. As such, the search for new approaches to resiliencebuilding - especially with regard to the livelihoods of the poor and marginalized - is revealed to be not merely a technical question, but also a contested political one. 


\section{References}

Adams, A. W. (2010): Planning for cruise ship resilience: an approach to managing cruise ship impacts in Haines, Alaska. In: Coastal Management 38 (6), 654-664. DOI: 10.1080/08920753.2010.529035

Adger, N. W. (2000): Social and ecological resilience: are they related? In: Progress in Human Geography 24 (3), 347-364. DOI: 10.1191/030913200701540465

Adger, N. W.; Kelly, P. M.; Winkels, A.; Huy, L. Q. and LocKe, C. (2002): Migration, remittances, livelihood trajectories, and social resilience. In: Ambio 31 (4), 358366. DOI: 10.1579/0044-7447-31.4.358

Adger, N. W.; Hughes, T. P.; Folke, C.; Carpenter, S. R. and Rockström, J. (2005): Social-ecological resilience to coastal disasters. In: Science 309 (5737), 1036-1039. DOI: $10.1126 /$ science. 1112122

Adger, W. N.; Dessai, S.; Goulden, M.; Hulme, M.; LorenZoni, I.; Nelson, D. R.; Neass, L. O.; Wolf, J. and WrEFORD, A. (2009): Are there social limits to adaptation to climate change? In: Climatic Change 93 (3-4), 335-354. DOI: $10.1007 /$ s10584-008-9520-z

Adger, W. N.; Brown, K.; Nelson, D. R.; Berkes, F.; EAKIN, H.; Folke, C.; Galvin, K.; Gunderson, L.; Goulden, M.; O’Brien, K.; Ruttenbeek, J. and Tompkins, E. L. (2011): Resilience implications of policy responses to climate change. Wiley Interdisciplinary Reviews: Climate Change 2 (5), 757-766. DOI: 10.1002/wcc.133

Béné, C.; Wood, R. G.; Newsham, A. and Davies, M. (2012): Resilience: new utopia or new tyranny? Reflection about the potentials and limits of the concept of resilience in relation to vulnerability reduction programmes. IDS Working Paper 2012 (405).

Berkes, F.; Colding, J. and Folke, C. (2003): Navigating social-ecological systems. Building resilience for complexity and change. Cambridge.

Biggs, D.; Hall, C. M. and Stoeckl, N. (2012): The resilience of formal and informal tourism enterprises to disasters: reef tourism in Phuket, Thailand. In: Journal of Sustainable Tourism 20 (5), 645-665. DOI: 10.1080/09669582.2011.630080

Bodin, Ö.; Crona, B. and Ernstson, H. (2006): Social networks in natural resource management: what is there to learn from a structural perspective? In: Ecology and Society 11 (2), r2. http://www.ecologyandsociety.org/ vol11/iss $2 /$ resp2/

BoHLE, H.-G. (2006): Soziales oder unsoziales Kapital? Das Sozialkapital-Konzept in der Geographischen Verwundbarkeitsforschung. In: Geographische Zeitschrift 93 (2), 65-81.

Bohle, H.-G.; Etzold, B. and Keck, M. (2009): Resilience as agency. In: IHDP-Update 2, 8-13.

Bouzarovski, S.; Salukvadze, J. and Gentile, M. (2011): A socially resilient urban transition? The contested land- scapes of apartment building extensions in two postcommunist cities. In: Urban Studies 48 (13), 2689-2714. DOI: $10.1177 / 0042098010385158$

Bradley, D. and Grainger, A. (2004): Social resilience as a controlling influence on desertification in Senegal. In: Land Degradation \& Development 15 (5), 451-470. DOI: $10.1002 / \mathrm{ddr} .628$

Brand, F. S. and Jax, K. (2007): Focusing the meaning(s) of resilience: resilience as a descriptive concept and a boundary object. In: Ecology and Society 12 (1), 23.

Braun, B. and AßHeuer, T. (2011): Floods in megacity environments: vulnerability and coping strategies of slum dwellers in Dhaka/Bangladesh. In: Natural Hazards 58 (2), 771-787. DOI: 10.1007/s11069-011-9752-5

CAnnon, T. (2008): Reducing people's vulnerability to natural hazards communities and resilience. In: WIDER Research Paper 2008 (34). Bonn. http://www.wider.unu.edu/ publications/working-papers / research-papers/2008/ en_GB/rp2008-34/_files/79269469163225299/default/rp2008-34.pdf

Cannon, T. and Müller-Mahn, D. (2010): Vulnerability, resilience and development discourses in context of climate change. In: Natural Hazards 55 (3), 621-635. DOI: 10.1007/s11069-010-9499-4

Carpenter, S.; Brock, W. and Hanson, P. (1999): Ecological and Social Dynamics in Simple Models of Ecosystem Management. In: Conservation Ecology 3 (2): 4. http:// www.consecol.org/vol3/iss2/art4/

Carpenter, S.; Walker, B.; Anderies, J. M. and Abel, N. (2001): From metaphor to measurement: resilience of what to what? In: Ecosystems 4, 765-781. DOI: 10.1007/s10021-001-0045-9

Cashman, A. C. (2011): Case study of institutional and social responses to flooding: reforming for resilience? In: Journal of Flood Risk Management 4 (1), 33-41. DOI: 10.1111/j.1753-318X.2010.01087.x

Christensen, L. and Krogman, N. (2012): Social thresholds and their translation into social-ecological management practices. In: Ecology and Society 17 (1), 5. DOI: 10.5751/ES-04499-170105

Cinner, J.; Fuentes, M. M. P. B. and Randriamahazo, H. (2009): Exploring social resilience in Madagascar's marine protected areas. In: Ecology and Society 14 (1), 41. http://www.ecologyandsociety.org/vol14/iss1/art41/

Cutter, S. L.; Barnes, L.; Berry, M.; Burton, C.; Evans, E.; TAte, E. and WebB, J. (2008): A place-based model for understanding community resilience to natural disasters. In: Global Environmental Change 18 (4), 598606. http://www.sciencedirect.com/science/article/ B6VFV-4TPF8Y8-1/2/da1135c28f390b65d9a9bbef8e 713b9d

Davidson, D. J. (2010): The applicability of the concept of resilience to social systems: some sources of optimism 
and nagging doubts. In: Society \& Natural Resources 23 (12), 1135-1149. DOI: 10.1080/08941921003652940

Deshingkar, P. (2012): Environmental risk, resilience and migration: implications for natural resource management and agriculture. In: Environmental Research Letters 7 (1), 015603. DOI: 10.1088/1748-9326/7/1/015603

Dongus, S.; Pfeiffer, C.; Metta, E.; Mbuyita, S. and OвRIST, B. (2010): Building multi-layered resilience in a malaria control programme in Dar es Salaam, Tanzania. In: Progress in Development Studies 10 (4), 309-324. DOI: $10.1177 / 146499340901000404$

ENDFIELD, G. H. (2007): Archival explorations of climate variability and social vulnerability in colonial Mexico. In: Climatic Change 83 (1-2), 9-38. DOI: 10.1007/s10584-006-9125-3

ERnstson, H. (2008): The social production of ecosystem services: lessons from urban resilience research. In: ERNSTSON, H.: In Rhizomia: Actors, networks and resilience in urban landscapes. PhD Thesis. Stockholm, 155-183.

Ernstson, H.; Barthel, S.; Andersson, E. and Borgström, S. (2010a): Scale-crossing brokers and network governance of urban ecosystem services: the case of Stockholm. In: Ecology and Society 15 (4), 28. http://www. ecologyandsociety.org/vol15/iss4/art28/

Ernstson, H.; van der Leeuw, S.; Redman, C.; Meffert, D.; Davis, G.; Alfsen, C. and Elmovist, T. (2010b): Urban transitions: on urban resilience and human-dominated ecosystems. In: AMBIO 39 (8), 531-545. DOI: 10.1007/ s13280-010-0081-9

Escobar, A. (1999): After nature. Steps to an antiessentialist political ecology. In: Current Anthropology 40 (1), 1-30. DOI: $10.1086 / 515799$

Etzold, B.; JÜlich, S.; KeCK, M.; SAKDAPOLRAK, P.; SCHMitT, T. and Zimmer, A. (2012): Doing institutions. A dialectic reading of institutions and social practices and its relevance for development geography. In: Erdkunde 66 (3), 185-195. DOI: 10.3112/erdkunde.2012.03.01

Evans, G. R. (2008): Transformation from "Carbon Valley" to a "Post-Carbon Society" in a climate change hot spot: the coalfields of the Hunter Valley, New South Wales, Australia. In: Ecology and Society 13 (1), 39. http:// www.ecologyandsociety.org/vol13/iss1/art39/

Folke, C. (2006): Resilience. The emergence of a perspective for social-ecological systems analysis. In: Global Environmental Change 16 (3), 253-267. DOI: 10.1016/j. gloenvcha.2006.04.002

Folke, C.; Carpenter, S. R.; Walker, B.; Scheffer, M.; Chapin, T. and Rockström, J. (2010): Resilience thinking: integrating resilience, adaptability and transformability. In: Ecology and Society 15 (4), 20. http:/ /www. ecologyandsociety.org/vol15/iss4/art20/

FOR 1501 (2010): Proposal for the establishment and funding of a research unit (RU) resilience, collapse and reorganisation in social-ecological systems of East- and
South Africa's savannahs. Preamble. Bonn and Cologne, 1-43. (unpubl. proposal)

Frazier, T. G.; Wood, N. and Yarnal, B. (2010): Stakeholder perspectives on land-use strategies for adapting to climate-change-enhanced coastal hazards: Sarasota, Florida. In: Applied Geography 30 (4), 506-517. DOI: 10.1016/j.apgeog.2010.05.007

Furedi, F. (2007): The changing meaning of disaster. In: Area 39 (4), 482-489.

GALlopín, G. C. (2006): Linkages between vulnerability, resilience, and adaptive capacity. In: Global Environmental Change 16 (3), 293-303. DOI: 10.1016/j.gloenvcha.2006.02.004

GARSCHAGEN, M. (2011): Resilience and organisational institutionalism from a cross-cultural perspective: an exploration based on urban climate change adaptation in Vietnam. In: Natural Hazards. DOI: 10.1007/s11069-011-9753-4

Glavovic, B. C.; Scheyvens, R. A. and Overton, J. D. (2003): Waves of adversity, layers of resilience: exploring the sustainable livelihoods approach. In: STOREY, D.; Overton, J. and Eds, B. N. (eds.): Contesting development: pathways to better practice. Proceedings of $3 \mathrm{rd}$ Biennial Conference of the Aotearoa New Zealand International Development Network (DevNet). Palmerston North, NZ, 289-293.

Gooch, M.; Butler, J. R. A.; Cullen-Unsworth, L. C.; RigAno, D. and Manning, C. (2012): Community-derived indicator domains for social resilience to water quality decline in a Great Barrier Reef catchment, Australia. In: Society \& Natural Resources 25 (5), 421-439. DOI: 10.1080/08941920.2011.608183

Greiner, C. and SAKDAPOLRAK, P. (2012): Rural-urban-migration, agrarian change and the environment in Kenya. A critical review of the literature. In: Population \& Environment, online first. DOI: $10.1007 /$ s11111-012-0178-0

- (2013): Translocality: concepts, applications and emerging research perspectives. In: Geography Compass. (prepress)

Gunderson, L. H. and Holling, C. S. (eds.) (2002): Panarchy: understanding transformations in human and natural systems. Washington, D.C.

HaAse, D. (2011): Participatory modelling of vulnerability and adaptive capacity in flood risk management. In: Natural Hazards. DOI: 10.1007/s11069-010-9704-5

Harte, E. W.; Childs, I. R. W. and Hastings, P. A. (2009): Imizamo Yethu: a case study of community resilience to fire hazard in an informal settlement Cape Town, South Africa. In: Geographical Research 47 (2), 142-154. DOI: $10.1111 /$ j.1745-5871.2008.00561.x

Hayward, B. (2008): 'Nowhere far from the sea': political challenges of coastal adaptation to climate change in New Zealand. In: Political Science 60 (1), 47-59. DOI: 10.1177/003231870806000105 
Hoy, D.; Southavilay, K.; Chanlivong, N.; Phimphachanh, C.; Dounngrhachanh, V. and Toole, M. J. (2008): Building capacity and community resilience to HIV: a project designed, implemented, and evaluated by young Lao people. In: Global Public Health 3 (1), 47-61. DOI: 10.1080/17441690701192022

Holling, C. S. (1973): Resilience and stability of ecological systems. In: Annual Review of Ecology and Systematics 4, 1-23.

- (1986): The resilience of terrestrial ecosystems: local surprise and global change. In: CLARK, W. C. and MunN, R. E. (eds.): Sustainable development of the biosphere. London, 292-317.

- (1996): Engineering resilience versus ecological resilience. In: Schulze, P. (ed.): Engineering within ecological constraints. Washington D.C., 31-44.

- (2001): Understanding the complexity of economic, ecological, and social systems. In: Ecosystems 4, 390-405.

Howe, P. D. (2011): Hurricane preparedness as anticipatory adaptation: a case study of community businesses. Global Environmental Change-Human and Policy Dimensions 21 (2), 711-720.

Hutter, G. (2011): Organizing social resilience in the context of natural hazards: a research note. In: Natural Hazards. DOI: 10.1007/s11069-010-9705-4

Judkins, G.; Smith, M. and Keys, E. (2008): Determinism within human-environment research and the rediscovery of environmental causation. In: The Geographical Journal 174 (1), 17-29. DOI: 10.1111/j.14754959.2008.00265.x

Kates R. W. and Clark W. C. (1996): Environmental surprise. Expecting the unexpected. In: Environment, 38 (2), 6-18. DOI: 10.1080/00139157.1996.9933458

KECK, M. (2012): Market governance and social resilience. The organization of food wholesaling in Dhaka, Bangladesh. Unpubl. PhD Thesis. Bonn.

Keck, M. and Etzold, B. (2013): Resilience refused. Wasted potentials for improving food security in Dhaka. In: Erdkunde 67 (1), 75-91 (in this volume.) DOI: 10.3112/erdkunde.2013.01.07

Keck, M.; Bohle, H.-G. and Zingel, W.-P. (2012): Dealing with insecurity. Informal business relations and risk governance among food wholesalers in Dhaka, Bangladesh. In: Zeitschrift für Wirtschaftsgeographie $56(1+2)$, $43-57$

Kunlicke, C. (2010): Resilience: a capacity and a myth: findings from an in-depth case study in disaster management research. In: Natural Hazards. DOI: 10.1007/ s11069-010-9646-y

Langridge, R.; Christian-Smith, J. and Lohse, K. A. (2006): Access and resilience: analyzing the construction of social resilience to the threat of water scarcity. In: Ecology and Society 11 (2), 18. http://www.ecologyandsociety. org/vol11/iss2/art18/
Larsen, R.; Calgaro, E. and Thomalla, F. (2011): Governing resilience building in Thailand's tourism-dependent coastal communities: conceptualising stakeholder agency in social-ecological systems. In: Global Environmental Change 21 (2), 481-491. DOI: 10.1016/j.gloenvcha.2010.12.009

Leichenko, R. and O'Brien, K. (2008): Environmental change and globalization: Double exposures. Oxford.

Leipert, B. D. and Reuter, L. (2005): Developing resilience: how women maintain their health in northern geographically isolated settings. In: Qualitative Health Research 15 (1), 49-65. DOI: 10.1177/1049732304269671

Lidskog, R. (2001): The re-naturalization of society? Environmental challenges for sociology. In: Current Sociology 49 (1), 113 -136. DOI: 10.1177/0011392101049001007

Lopez-Marrero, T. and Tschakert, P. (2011): From theory to practice: building more resilient communities in flood-prone areas. In: Environment and Urbanization 23 (1), 229-249. DOI: 10.1177/0956247810396055

Lorenz, D. (2010): The diversity of resilience: contributions from a social science perspective. In: Natural Hazards. DOI: 10.1007/s11069-010-9654-y

LyON, C. J. (2011): Exploring dimensions of place-power and culture in the social resilience of forest-dependent communities. Edmonton, Alberta.

Manyena, S. B. (2006): The concept of resilience revisited. In: Disasters 30 (4), 433-50. DOI: 10.1111/j.03613666.2006.00331.x

Marshall, N. A. (2007): Can policy perception influence social resilience to policy change? In: Fisheries Research 86 (2-3), 216-227. DOI: 10.1016/j.fishres.2007.06.008

- (2010): Understanding social resilience to climate variability in primary enterprises and industries. In: Global Environmental Change 20 (1), 36-43. DOI: 10.1016/j. gloenvcha.2009.10.003

Marshall, N. A. and Marshall, P. A. (2007): Conceptualizing and operationalizing social resilience within commercial fisheries in northern Australia. In: Ecology and Society 12 (1), 1. http://www.ecologyandsociety.org/vol12/iss1/art1/

Marshall, N. A.; Fenton, D. M.; Marshall, P. A. and SutTon, S. G. (2007): How resource dependency can influence social resilience within a primary resource industry. In: Rural Sociology 72 (3), 359-390. DOI: 10.1526/003601107781799254

Marshall, N. A.; Marshall, P. A. and Abdulla, A. (2009): Using social resilience and resource dependency to increase the effectiveness of marine conservation initiatives in Salum, Egypt. In: Environmental Planning and Management 52 (7), 901-918. DOI: 10.1080/09640560903180982

Marshall, N. A.; Gordon, I. J. and Ash, A. J. (2011): The reluctance of resource-users to adopt seasonal climate forecasts to enhance resilience to climate variability on the rangelands. In: Climatic Change 107 (3-4), 511-529. DOI: 10.1007/ s10584-010-9962-y 
MAYunGa, J. S. (2007): Understanding and applying the concept of community disaster resilience: a capital-based approach. Working paper for the summer academy for social vulnerability and resilience building, 22-28 July 2007. Munich.

McGee, T. K. (2011): Public engagement in neighbourhood level wildfire mitigation and preparedness: case studies from Canada, the US and Australia. In: Environmental Management 92 (10), 2524-2532. DOI: 10.1016/j.jenvman.2011.05.017

McSweeney, K. and Coomes, O. T. (2011): Climate-related disaster opens a window of opportunity for rural poor in northeastern Honduras. In: Proceedings of the National Academy of Sciences of the United States of America 108 (13), 5203-5208. DOI: 10.1073/pnas.1014123108

Miller, F.; Osbahr, H.; Boyd, E.; Thomalla, F.; Bharwani, S.; Ziervogel, G.; Walker, B.; Birkmann, J.; VAN DER Leeuw, S.; Rockström, J.; Hinkel, J.; Downing, T.; Folke, C. and NelsON, D. (2010): Resilience and vulnerability: complementary or conflicting concepts? In: Ecology and Society 15 (3), 11. http:/ /www.ecologyandsociety.org/vol15/iss3/art11/

Müller-Mahn, D. and Everts, J. (2013). Riskscapes. Spatial dimension of risk. In: MülLER-MAHN, D. (ed.): The spatial dimension of risk. How geography shapes the emergence of riskscapes. London, 22-36.

MustafA, D. (2005): The production of an urban hazardscape in Pakistan: modernity, vulnerability, and the range of choice. In: Annals of the Association of American Geographers 95(3), 566-586. DOI: 10.1111/j.1467-8306.2005.00475.x

Moore, M.-L. and Westley, F. (2011): Surmountable chasms: networks and social innovation for resilient systems. In: Ecology and Society 16 (1), 5. http:/ /www.ecologyandsociety.org/vol16/iss1/art5/

Nelson, D. R.; Adger, N. W. and Brown, K. (2007). Adaptation to environmental change: contributions of a resilience framework. In: Annual Review of Environment and Resources, 32 (1), 395-419. DOI: 10.1146/annurevenergy.32.051807.090348

Obrist, B.; Pfeiffer, C. and Henley, R. (2010a): Multi-layered social resilience: a new approach in mitigation research. In: Progress in Development Studies 10 (4), 283-293. DOI: 10.1177/146499340901000402

Obrist, B.; Mayumana, I. and Kessy, F. (2010b): Livelihood, malaria and resilience: a case study in the Kilombero Valley, Tanzania. In: Progress in Development Studies 10 (4): 325-343. DOI: $10.1177 / 146499340901000405$

OLWIG, M. F. (2012): Multi-sited resilience: the mutual construction of "local" and "global" understandings and practices of adaptation and innovation. In: Applied Geography 33, 112-118. DOI: 10.1016/j.apgeog.2011.10.007

O'Brien, K. (2011). Responding to environmental change: a new age for human geography? In: Progress in Human Geography, 35 (4), 542-549. DOI: $10.1177 / 0309132510377573$
O'Brien, K.; Hayward, B. and Berkes, F. (2009): Rethinking social contracts: building resilience in a changing climate. In: Ecology and Society 14 (2), 12. http://www. ecologyandsociety.org/vol14/iss2/art12/

Pearce, M.; Willis E.; Wadham, B. and Binks, B. (2010): Attitudes to drought in outback communities in South Australia. In: Geographical Research 48 (4), 359-369. DOI: $10.1111 /$ j.1745-5871.2009.00639.x

Pelling, M. (2003): The vulnerability of cities: natural disasters and social resilience. London.

Pelling, M. and High, C. (2005): Understanding adaptation: what can social capital offer assessments of adaptive capacity? In: Global Environmental Change 15 (4), 308-319. DOI: 10.1016/j.gloenvcha.2005.02.001

Pelling, M. and Manuel-Navarrete, D. (2011): From resilience to transformation: the adaptive cycle in two Mexican urban centers. In: Ecology and Society 16 (2), 11. http://www.ecologyandsociety.org/vol16/iss2/art11/

Perz, S. G.; Cabrera, L.; Carvalho, L. A.; Castillo, J. and BARnes, G. (2010): Global economic integration and local community resilience: road paving and rural demographic change in the southwestern Amazon. In: Rural Sociology 75 (2), 300-325. DOI: 10.1111/j.15490831.2009.00008.x

PIMm, S. L. (1984): The complexity and stability of ecosystems. In: Nature 307, 321-326. DOI: 10.1038/307321a0

Porter, G.; Hampshire, K.; Kyei, P.; Adjaloo, M.; Rapoo, G. and Kilpatrick, K. (2008): Linkages between livelihood opportunities and refugee-host relations: learning from the experiences of Liberian camp-based refugees in Ghana. In: Journal of Refugee Studies 21 (2), 230 252. DOI: $10.1093 /$ jrs/fen015

Rasmussen, K.; May, W.; Birk, T.; Mataki, M.; Mertz, O. and Yee, D. (2009): Climate change on three Polynesian outliers in the Solomon Islands: impacts, vulnerability and adaptation. In: Geografisk Tidsskrift-Danish Journal of Geography 109 (1), 1-13.

Rockstrom, J. (2004): Making the best of climatic variability: options for upgrading rainfed farming in water scarce regions. In: Water Science and Technology, 49 (7), 151-156.

SAKDAPOLRAK, P. (2010): Orte und Räume der Health Vulnerability. Bourdieus Theorie der Praxis für die Analyse von Krankheit und Gesundheit in megaurbanen Slums von Chennai, Südindien. Saarbrücken.

Scheffran, J.; Marmer, E. and Sow, P. (2012): Migration as a contribution to resilience and innovation in climate adaptation: social networks and co-development in Northwest Africa. In: Applied Geography 33, 119-127. DOI: 10.1016/j.apgeog.2011.10.002

Schwarz, A.-M.; Béné, C.; Bennett, G.; Boso, D.; Hilly, Z.; Paul, C.; Posala, R.; Sibiti, S. and Andrew, N. (2011): Vulnerability and resilience of remote rural communities to shocks and global changes: empirical analysis from 
Solomon Islands. In: Global Environmental Change 21 (3), 1128-1140. DOI: 10.1016/j.gloenvcha.2011.04.011

SIEGmann, K. A. (2010): Strengthening whom? The role of international migration for women and men in Northwest Pakistan. In: Progress in Development Studies 10 (4), 345361. DOI: $10.1177 / 146499340901000406$

STAR, S. L. 2010: This is not a boundary object: reflections on the origin of a concept. In: Science, Technology, \& Human Values 35(5), 601-617. DOI: $10.1177 / 0162243910377624$

STAR, S. L. and Griesemer, J. R. (1989): Institutional ecology, 'translations' and boundary objects: amateurs and professionals in Berkeley's museum of vertebrate zoology, 190739. In: Social Studies of Science 19 (3), 387-420. DOI: 10.1177/030631289019003001

Streets, D. G. and Glantz, M. H. (2000): Exploring the concept of climate surprise. In: Global Environmental Change, 10, 97-107. DOI: 10.1016/S0959-3780(00)00015-7

Thomas, D. S. G. and Twrman, C. (2005): Equity and justice in climate change adaptation amongst natural-resource-dependent societies. In: Global Environmental Change 15 (2), 115-124. DOI: 10.1016/j.gloenvcha.2004.10.001

Tobin, G. A. and Whiteford, L. M. (2002): Community resilience and volcano hazard: the eruption of Tungurahua and evacuation of the Faldas in Ecuador. In: Disasters 26 (1), 28-48. DOI: 10.1111/1467-7717.00189

TOMPKINS, E. L. (2005): Planning for climate change in small islands: Insights from national hurricane preparedness in the Cayman Islands. In: Global Environmental Change 15 (2), 139-149. DOI: 10.1016/j.gloenvcha.2004.11.002

Traerup, S. (2012): Informal networks and resilience to climate change impacts: a collective approach to index insurance. In: Global Environmental Change 22 (1), 255-267. DOI: 10.1016/j.gloenvcha.2011.09.017

Turner, B. L.; Kasperson, R.; Matson, P; McCarthy, J.; Corell, R.; Christensen, L.; Eckley, N.; Kasperson, J.; Luers, A.; Martello, M.; Polsky, C.; Pulsipher, A. and Schiller, A. (2003): A framework for vulnerability analysis in sustainability science. In: Proceedings of the National Academy of Sciences of the United States of America 100 (14), 8074-8079.

Varghese, J.; Krogman N. T.; Beckley, T. M. and Nadeau, S. (2006): Critical analysis of the relationship between local ownership and community resiliency. In: Rural Sociology 71 (3), 505-527. DOI: 10.1526/003601106778070653

Voss, M. (2008): The vulnerable can't speak. An integrative vulnerability approach to disaster and climate change research. In: Behemoth 1 (3), 39-56. DOI: 10.1524/behe.2008.0022

WALKER, B. (1993): Rangeland ecology: understanding and managing change. In: Ambio 22 (2/3), 80-87

WaLker, B. H. and SAlt, D. (2006): Resilience thinking: sustaining ecosystems and people in a changing World. Washington, D.C.
Walker, B. H.; Ludwig, D.; Holling, C. S. and Peterman, R. M. (1981): Stability of semi-arid savanna grazing systems. In: Journal of Ecology 69 (2), 473-498. DOI: $10.2307 / 2259679$

Walker, B. H.; Carpenter, S. R.; Anderies, J. M.; Abel, N.; Cumming, G. S.; Janssen, M. A.; Lebel, L.; Norberg, J.; Peterson, G. D. and Pritchard, R. (2002): Resilience management in social-ecological systems: a working hypothesis for a participatory approach. In: Conservation Ecology 6 (1), 14. http://www.consecol.org/vol6/iss1/ art14/

Walker, B. H.; Holding, C. S.; Carpenter, S. R. and Kinzig, A. (2004): Resilience, adaptability and transformability in social-ecological systems. In: Ecology and Society 9 (2), 5. http://www.ecologyandsociety.org/vol9/iss2/art5

Wolf, J.; Adger, W. N.; Lorenzoni, I.; Abrahamson, V. and RaIne, R. (2010). Social capital, individual responses to heat waves and climate change adaptation: an empirical study of two UK cities. In: Global Environmental Change 20 (1), 44-52. DOI: 10.1016/j.gloenvcha.2009.09.004

Zingel, W.-P.; Keck, M.; Etzold, B. and Bohle, H.-G. (2011): Urban food security and health status of the poor in Dhaka, Bangladesh. In: KrÄMer, A.; KHAN, M. H. and KrAAs, F. (eds.): Health in megacities and urban areas. Contributions to statistics. Heidelberg, 301-319. DOI: 10.1007/978-3-7908-2733-0_19

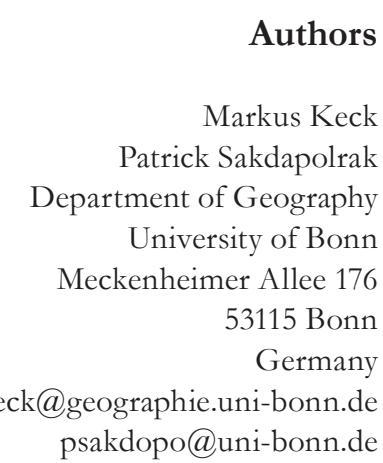

